\title{
A case of rescue archaeology in Ascoli Piceno: the project of San Pietro in Castello
}

\section{A Case of Rescue Archaeology in Ascoli Piceno: the Project of San Pietro In Castello}

The project, developed in collaboration between the Department of History and Culture-DISCI of the University of Bologna, the Soprintendenza Archeologia, Belle Arti e Paesaggio delle Marche and the Comune di Ascoli Piceno, took place in 2019 during the restoration of the area of San Pietro in Castello. The non-invasive survey was carried out using methodologies related to rescue archaeology and urban archaeology for the purpose of reconstructing the historical and archaeological development of this urban area. The considerations described in this paper are preliminary since the study is still in progress.

\section{Introduction'}

During the urban renovations realized by the Municipality of Ascoli Piceno in the environs of S. Pietro in Castello the University of Bologna carried out some research aimed at understanding the historical and archaeological development of this area and the existing Romanesque church. The project, still under study, was conducted using different methodologies used in rescue archaeology (Boschi 2016): the archival and bibliographic study of the area of S. Pietro in Castello, a noninvasive investigation of the subsoil by means of geophysical instrumentation, the analysis and stratigraphic reading of the walls of the church and of the surrounding walls and archaeological surveys. The results of this combined research have provided interesting data that could be the basis for future investigation.

1 Abstract, introduction, the first paragraph and the conclusions were written by Martina Bombardelli, the second paragraph by Giuseppe Guarino, the third by Federico Zoni and the fourth by Michele Massoni 


\section{Historical and geomorphological framework of San Pietro in Ca- stello area}

The Municipality of Ascoli Piceno is located at the junction of the high and low valley of the Tronto river. The old town centre is located on a wedge-shaped river terrace slightly sloping towards the north and north-east, and is surrounded by the two main rivers of the city, the Tronto and the Castellano. These river courses

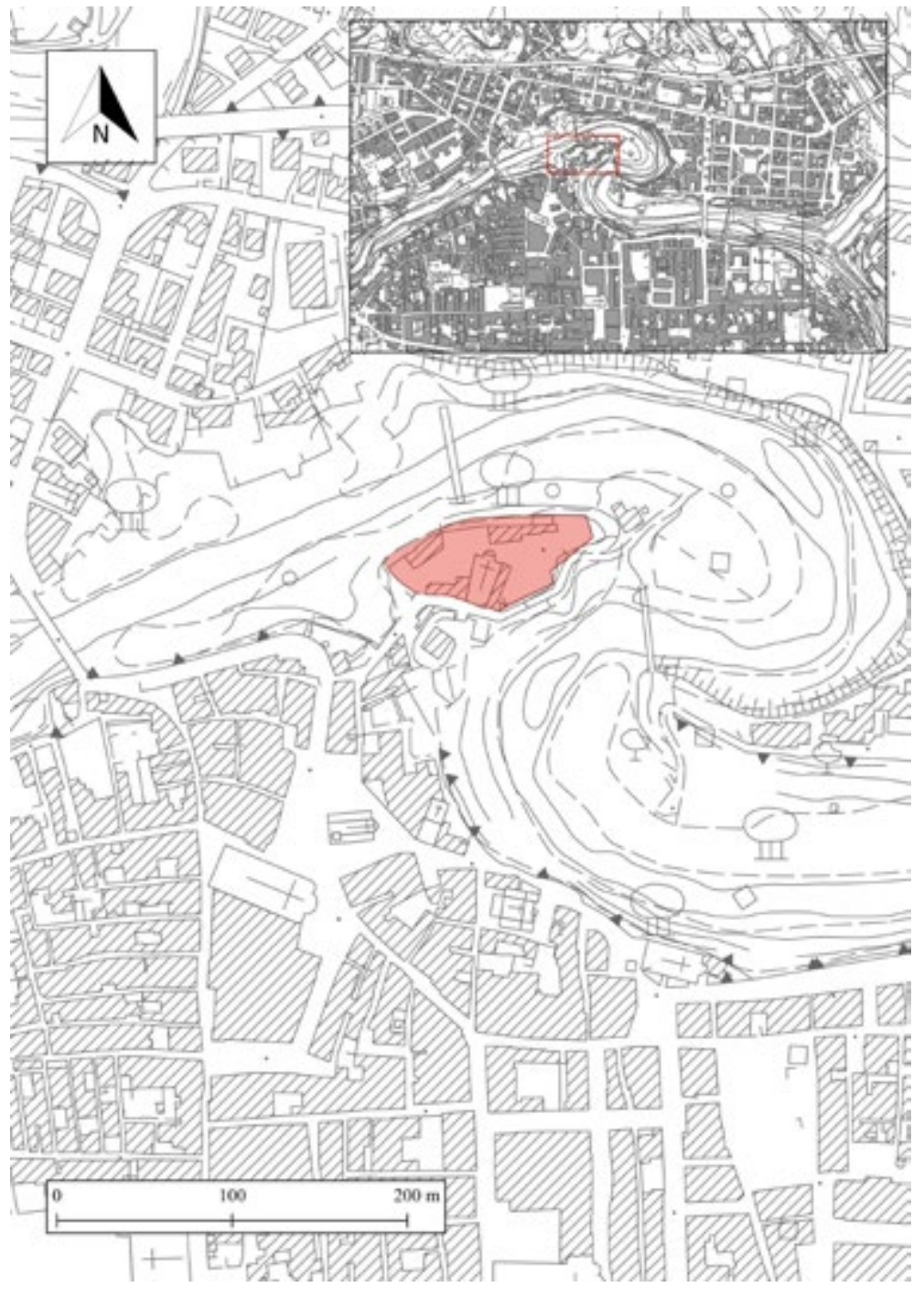

Fig. 1. General view of San Pietro in Castello area. surround the urban area along its entire perimeter, except the western side, where no natural defence exists (fig. 1).

The area of San Pietro in Castello, where the eponymous cultic building stan$\mathrm{ds}$, is located in the northern part of the city, on a meander bounded by the river Tronto and connected to the rest of the city in the south-western part (fig. $2)^{2}$.

The name of the ecclesiastical building comes from castellum de isola ${ }^{3}$, which refers to a presumable presence $\mathrm{du}-$ ring the Longobard period of a fortified residence (castellum) located on a promontory surrounded by the river Tronto and connected to the city by an isthmus (de isola or in Insula). A second name of the place, San Pietro all'Isola, is mentioned by the scholar Sebastiano Andreantonelli ${ }^{4}$ in reference to the high alluvial terrace where the church is located. The religious building of San Pietro in Castello as a whole represents one of the various examples of late Romanesque architectural techniques of the town. However, its current appearance, and consequently its walls, is actually the result of several centuries of alterations that this building underwent;

2 For the history of the city please see: Pasquinucci and Laffi 1975; De Maria and Giorgi 2014, 173-222; Giorgi 2000, 145-153; Giorgi 2014, 225-292; Paci 2014; Quilici 2007, 65-91; Staffa 2000, 417-436; Profumo 2005, 843-914.

3 Cappelli 2007, p. 142.

4 Andreantonelli 1673. 


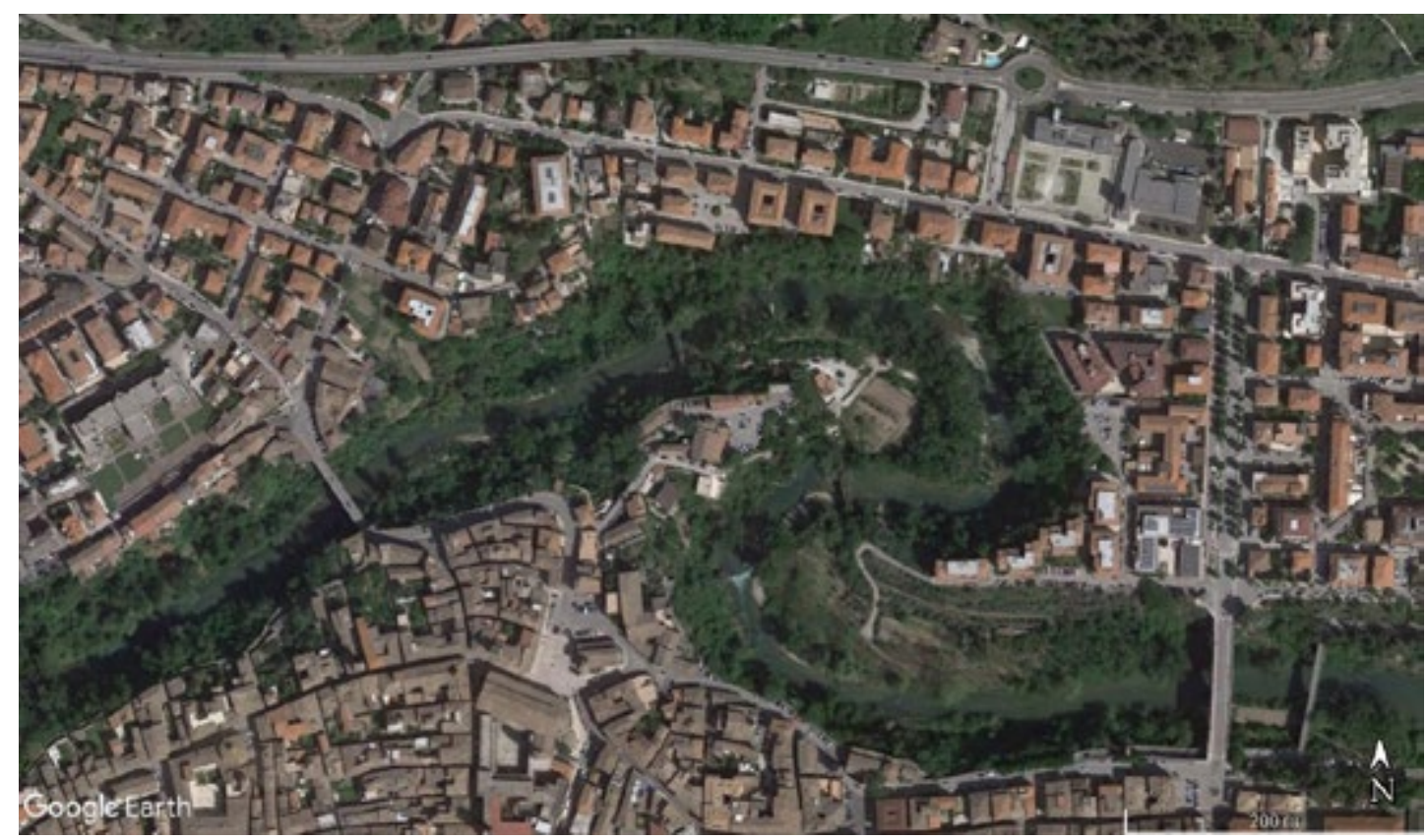

Fig. 2. The area of San

Pietro in Castello.

today it appears as a historical palimpsest that crosses the Middle Ages until the contemporary age.

In the history of local studies, the church has been ascribed to several chronologies, depending on the opinion of individual researchers. The various points of view can be substantially divided between those who tend to place the building which nowadays is visible in the 12th-13th century and on the other hand, those who consider it completely late medieval, with various phases ranging from the end of the 14 th century to the 15 th century ${ }^{5}$. Some sources consider that already in the 8 th century there was a church, no more identifiable, which belonged to the Longobard domination of the city ${ }^{6}$. This church was built by the will of Bishop Auclere: he is credited with the numerous foundations of Benedictine monasteries in the territory ${ }^{7}$. Thereafter, in 1069, Bishop Stefano pressed for the construction of a bell tower for defense ${ }^{8}$; this building was certainly still present in the mid-17th century, since it was documented in historical maps, in particular in Ferretti's map of 1646. As figure 3 shows, the area, surrounded by walls, is characterized by the presence of the Church of San Pietro in Castello and most easterly by the aforementioned tower.

5 For a brief history of studies, please refer to Fabiani 1951, 100-104. For an origin of the 12th century, please refer to Mariotti 1907, Varese 1953 and Carducci 1853. For the 13th century and the period between the 13th and the 14th century see Calzini 1915 e Serra 1936. For the 15th century see Fabiani 1951.

6 Carducci 1853, 154; Mariotti 1925, 104; Varese Rota 1942, 85; Cappelli 2007, 143.

7 Carducci 1853, 154; Mariotti 1925, 104.

8 Cappelli 2007, 143. 


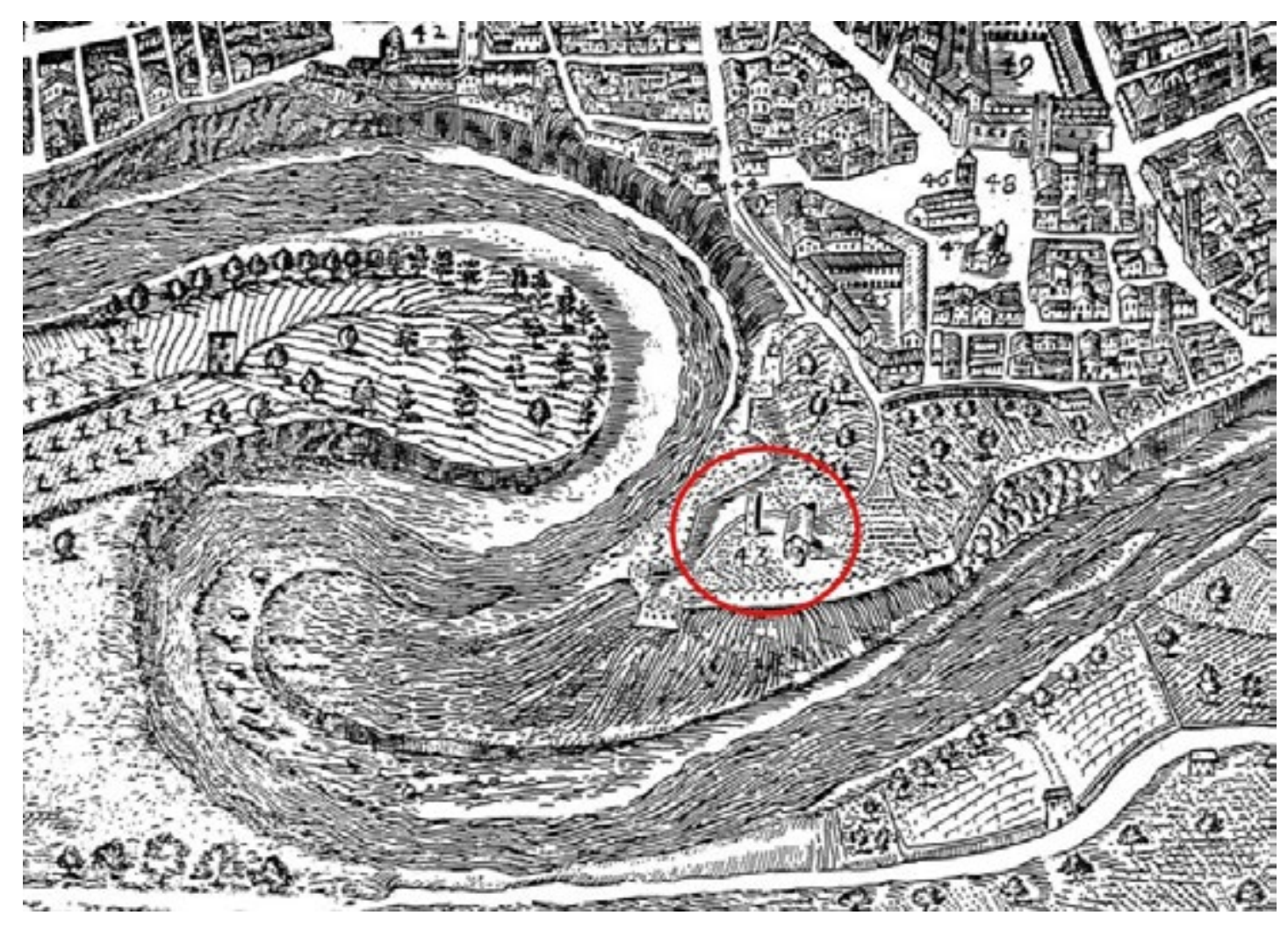

Fig. 3 Detail of the area in Ferretti's map (1646).

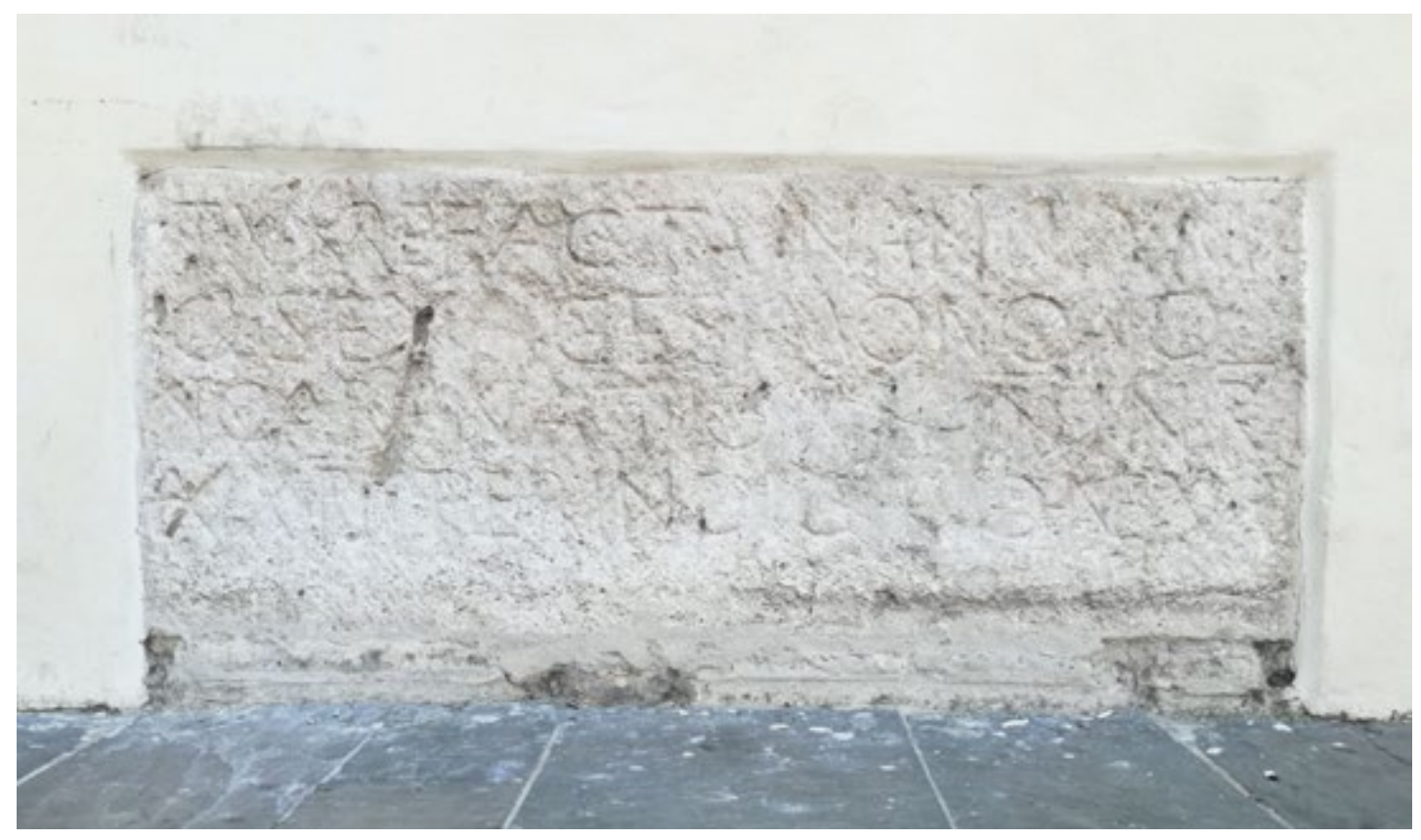

Fig. 4. The epigraph in the facade of the Bishop's Palace. 
Around 1747 some elements of the defensive structure were reused for the construction of the façade of the Bishop's Palace, including a plinth with an epigraph commemorating its construction' (fig. 4). In 1142 Varese reported the construction of a new church according to the will of the bishop Presbiterio ${ }^{10}$; the remains of San Benedetto of Benevento were moved into the new building during the church's consecration. However, another source only traces the displacement of the Saint in the 15th century, during the last renovation of the building". In 1192 the religious members of the Church of San Pietro in Castello became part of the order of the Canons Regular of St. Agostino. In addition Cappelli states that in 1289 the Church was under reconstruction ${ }^{12}$. Finally, according to Rodilossi ${ }^{13}$ the current appearance of the building apparently dates back to the reconstruction of the church between 1466 and 1472 and the work of the Comacine masters Giovanni di Ambrogio, Domenico di Donato and Cristoforo di Andrea, when the plan was presumably reduced and it became a single nave ${ }^{14}$. Once more the literature disagrees about the interpretation of the facade, i.e. whether the prospect relating to the last phase was the reduced reproduction of the previous one, as Cappelli believes, or whether it was pertinent to a new project, detached from the ancient model, as Fabiani ${ }^{15}$ thinks.

\section{Geophysical non-invasive survey: methodology and results.}

In order to carry out a mapping of the presence of archaeological evidence and/ or infrastructures and sub-services in the area of San Pietro in Castello, the Department of History and Culture- DISCI of the University of Bologna conducted geophysical prospection using Ground Penetrating Radar (GPR), covering a total area of $1800 \mathrm{~m}^{2}$; the surveys were also carried out at the narthex and the central nave of the $\operatorname{church}^{16}$ (fig. 5-7).

In the field, grids were set up in order to obtain the profiles, both parallel and orthogonal in a single direction, at a regular distance of $0.50 \mathrm{~m}$ (fig. 8). The grid limits were marked on the ground using small stakes and subsequently recorded

9 Rodilossi 1983, p. 145; Cappelli 2007, 143.

10 Fabiani 1951, 92.

11 Fabiani 1951, 93. Currently the sarcophagus of the Saint is kept in the crypt of the Cathedral, Cappelli 2007, 143.

12 Cappelli 2007, 143; Fabiani 1956, 101.

13 Rodilossi 1983, 145.

14 Fabiani 1951, 93; Cappelli 2007, 143.

15 Cappelli 2007, 144; Fabiani 1951, 94.

16 For other geophysics projects carried out in Ascoli Piceno by University of Bologna please see Boschi, Giorgi and Silani 2017, 301-309. Green areas were excluded from the survey because they were used for the storage of building materials during the works. 
Fig. 5. Survey on field using Ground Penetrating Radar

(GPR).

Fig. 6. Positioning of the geophysical grids.

Fig. 7. Positioning of the time-slice (depth of $0.60 \mathrm{~m}$ )
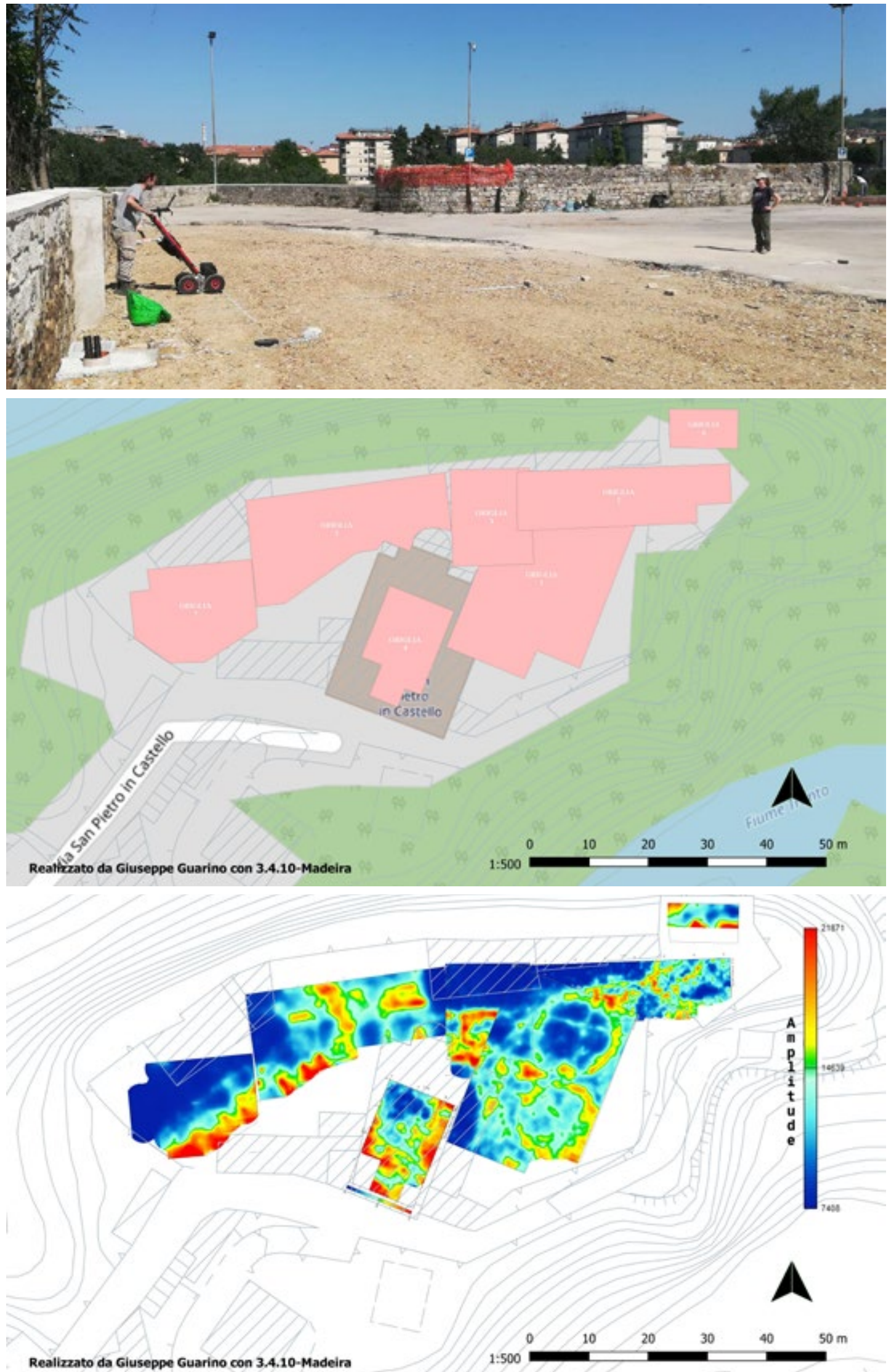
using a Total Station to allow their georeferencing in a GIS system.

The GPR surveys were performed by using IDS RIS MF Hi-Mod georadar equipment, with dual frequency antenna (200-600 MHz). All the antenna profiles were acquired with 512 sample/ track for the $600 \mathrm{MHz}$ antenna and 328 for the $200 \mathrm{MHz}$ antenna.

After the radar data collection, the profiles obtained from the $600 \mathrm{MHz}$ antenna, were processed by means of the Ground Penetrating Radar GPR-Slice software ${ }^{17}$.

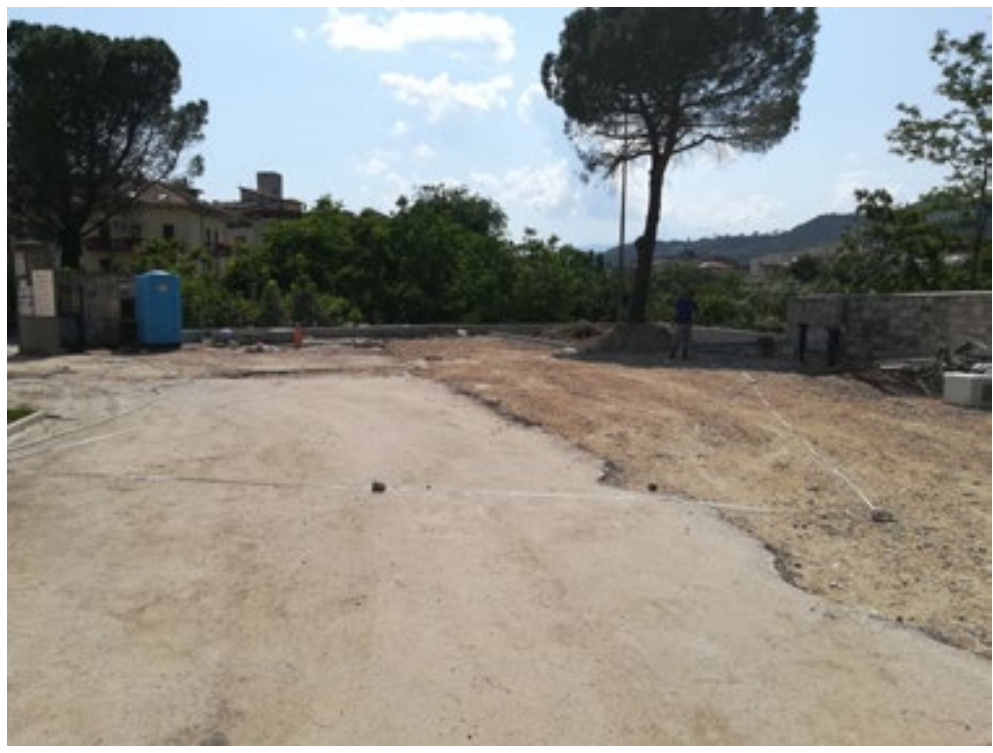

Analysing the traces reflected by the radargrams and time-slice ${ }^{18}$, the presence of modern structures is evident: in particular, in the small square on the east side of the church the high energy values visible in the radar profiles, related to wall structures, can be traced back to the foundations of silos existing in the area since the 1950s (fig. 9), clearly visible in the aerial photograph of 1958 (fig. 10). Moreover, there are some anomalies connected to them which are probably due to pipes associated to the modern structure (fig. 11). Also, on the north side of the church there are a series of high energy values denote high subsurface contrasts, probably related

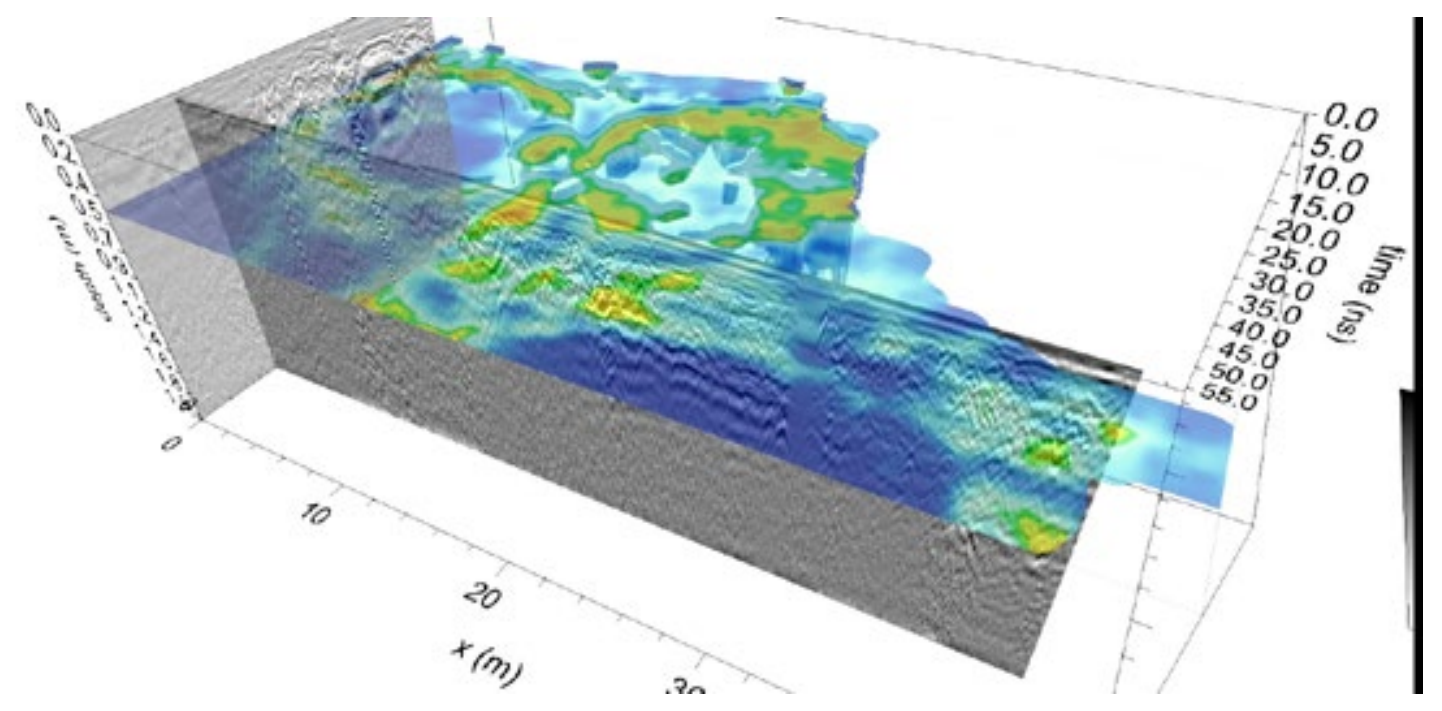

Fig. 8. Grid 6. Positioning of the GPR grid in order to obtain profiles.

Fig. 9 Pseudo-section 3D of Grid 1. In the horizontal section (slice) circular features can be observed at a depth of $0.50 \mathrm{~m}$ which relate to the pre-existing silos are observed (high yellow/green amplitude values) related to the pre-existing silos. The vertical profiles show a complex stratigraphic reality characterised by subservices and levels of floors and rubble.

17 The Software is marketed by Geophysical Archaeometry Laboratory Inc., available on the website: https://www.gpr-survey.com/

18 Conyers, L.B., Goodman. D. 1997. 


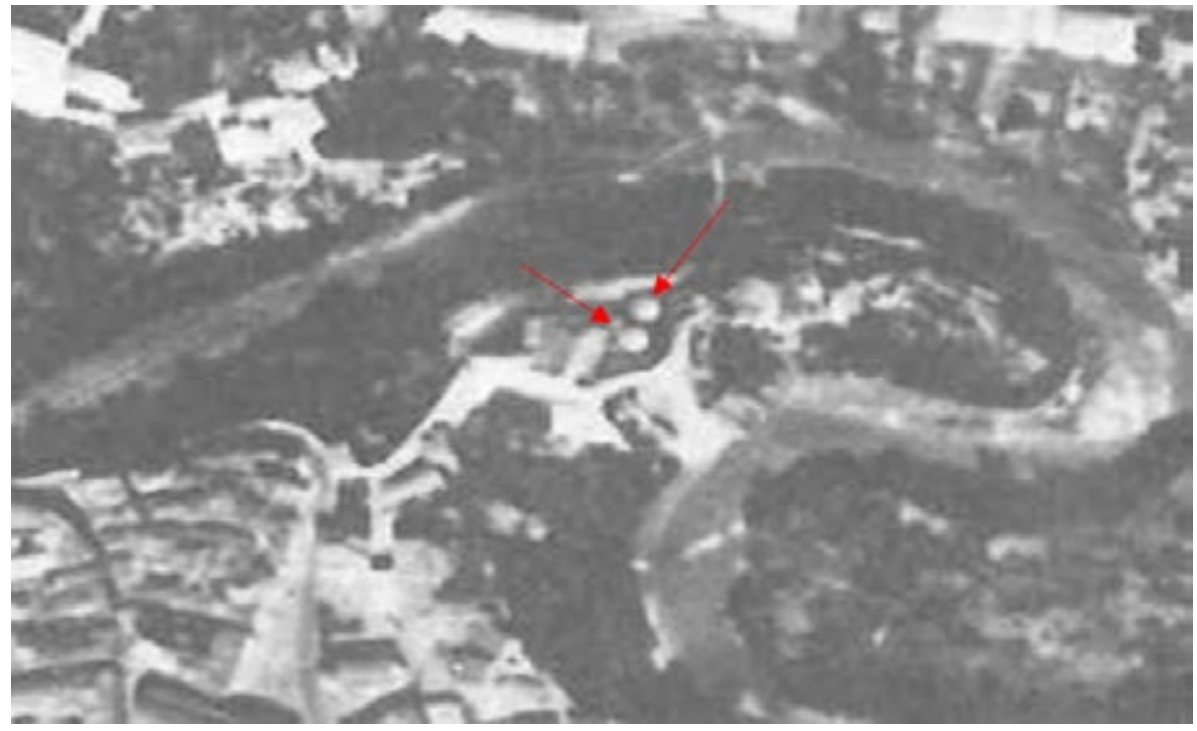

Fig. 10 Aerial photograph of the silos (1958).

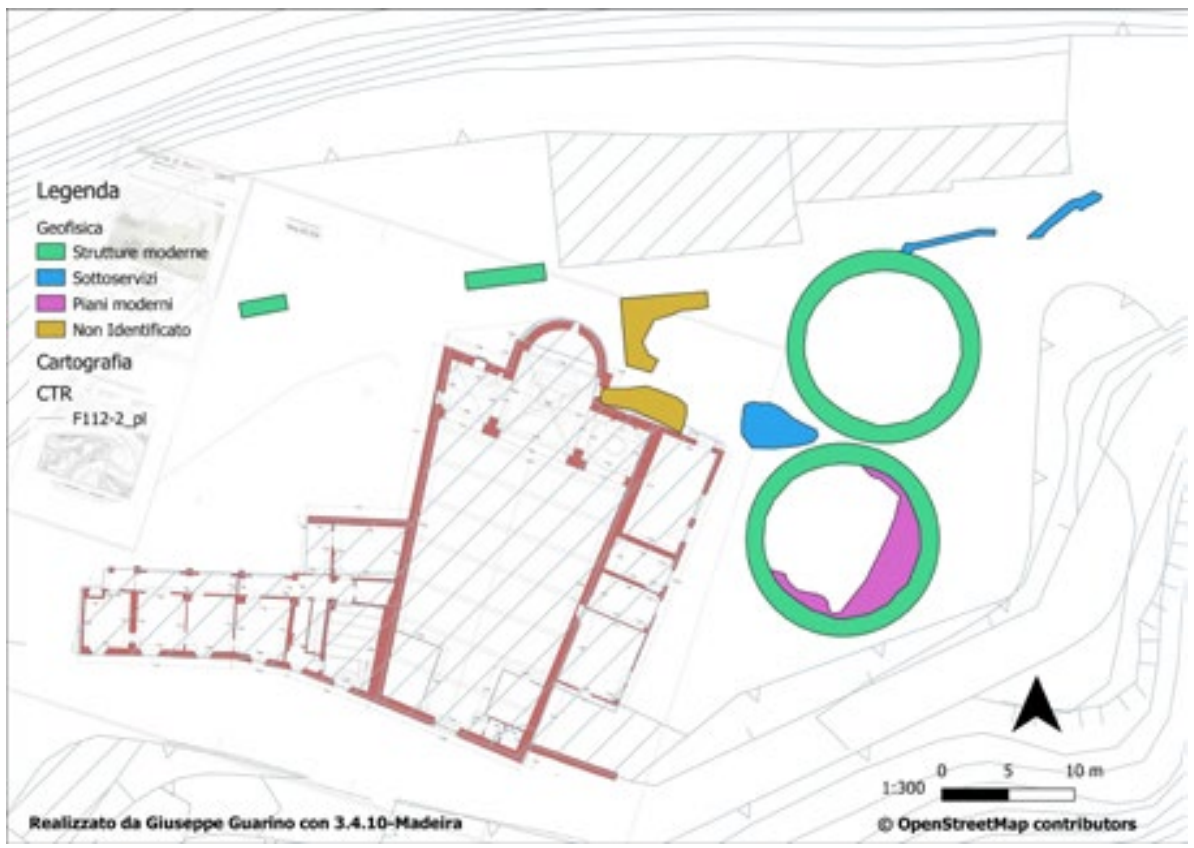

Fig. 11 Interpretative plan of the surveys in the parking area. to wall structures connected to the basement floors of modern buildings (Fig. 11 S3-S4 structures).

In relation to the results of the data analysed up to now, it is possible to determine the following:

- the parking area surrounding the Church of San Pietro in Castello has undergone some alterations in modern times due to the works for the construction of silos and houses with underground floors;

- due to the alterations caused by anthropic activity, the archaeological stratigraphy is difficult to read both in the vertical radar profiles and in the horizontal amplitude maps.

The most relevant data are the radargrams collected inside the church coming from the grid conducted inside the church. The presence of numerous reflections with the characteristic shape of hyperbole located at depths between 0 and $0.30 \mathrm{~m}$ should be taken into account; these anomalies correspond to the probable presence of elements related to the base of preparation of the pavement (earth mixed with pebbles, metal elements), visible on all the profiles collected in the area. These reflections create a downward disturbance, making it difficult to interpret the anomalies that are present at a greater depth. However, starting from a depth of about $0.70 \mathrm{~m}$ is possible catch a glimpse of the buried archaeological evidence in the narthex of the church. The high values visible in the radargrams show heterogeneities layers that can be attributed to the presence of structural evidence 


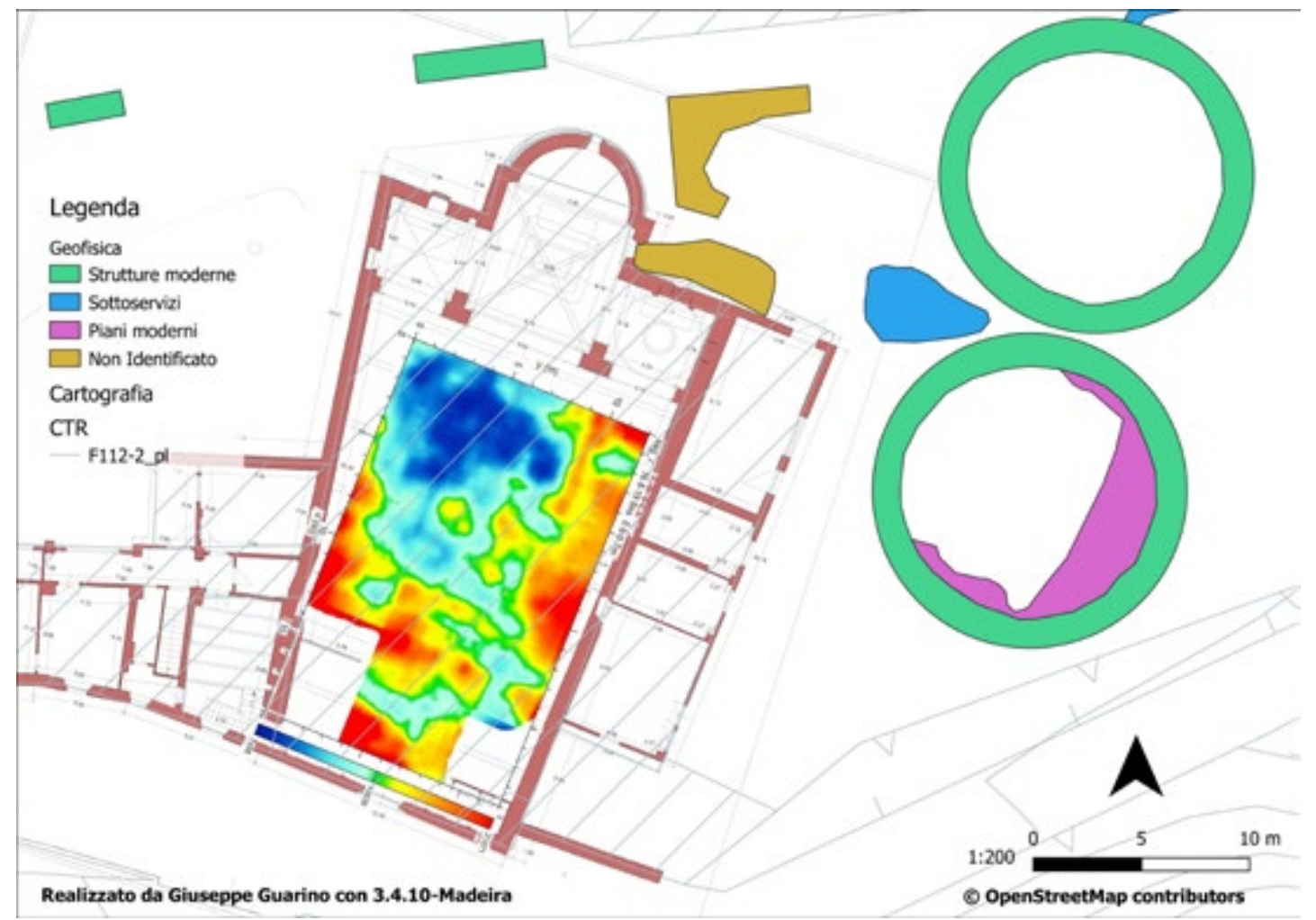

Fig. 12 Time-slice at a depth of $0.60 \mathrm{~m}$. The values of high amplification, in red, due to the presence of floors/structures related to a phase prior to the present church.

(fig. 12). By comparing GPR data with the stratigraphic analysis of the elevations (see paragraph 3), several interesting correspondences can be found for the southern front of the church, where it is possible to see a portion of a pre-existing brickwork, USM 208 (fig. 13), reused as a support for the construction of the church, in analogy to the suggestion derived from the geophysical investigation.

\section{Considerations of the architectural phases of the complex and analysis of the elevations.}

Between the different surveys carried out on the occasion of the restoration of the area by the Municipality of Ascoli Piceno, the team of the University of Bologna also made a stratigraphic analysis of the brickwork in the sector. Indeed, the analysis was not only limited to the structure of the medieval church, but also focused on the current substructures of the front square.

The methodological approach is based on the practice of architectural urban archaeology, namely the stratigraphic analysis of the elevations, through which it is possible to understand the various architectural phases present in the brickwork of the buildings ${ }^{19}$.

19 For the methodologies of architectural archaeology, please see Brogiolo, Cagnana 2012. 


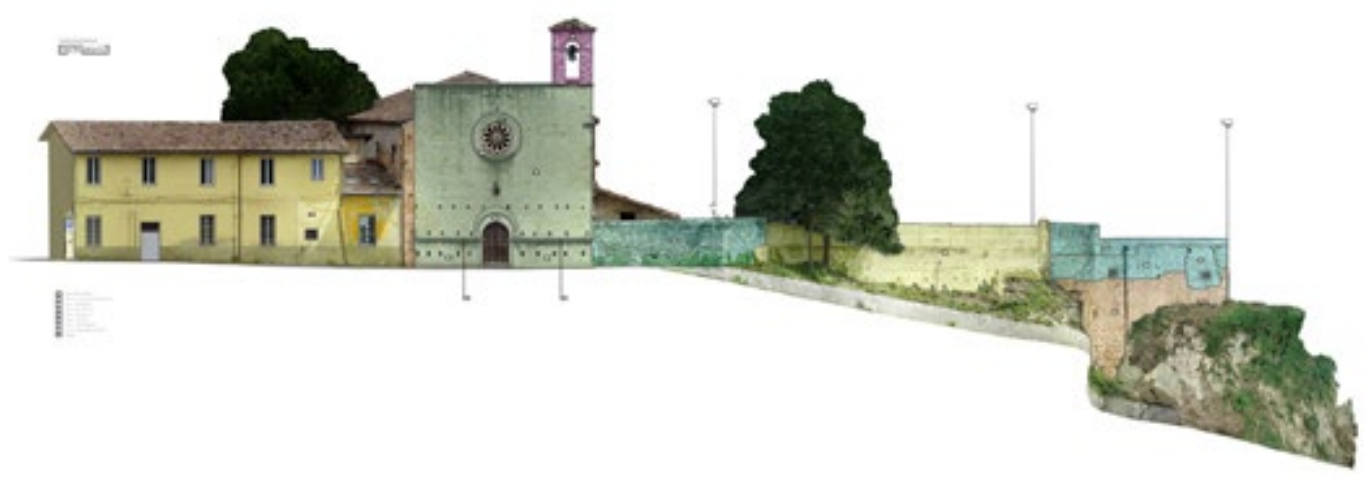

Fig. 13. Elevation of the south façade of the church.
In the specific case of San Pietro in Castello a total of 7 architectural phases have been found in the various elevations, ranging from the 11th-12th centuries, until the second post-war period.

However, the church does not seem to be the oldest survival of the area of San Pietro. In fact, it turned out to be a huge ecclesiastical building site of the mid13 th century. On the contrary, the underlying walls might be whatever remains of the structures of the castrum that gives the area its name, for which, in the absence of other information, it is possible only to suggest a chronology prior to the 13th century, probably dating back to the end of the 11th - full 12th century.

The work has all been developed and represented with the graphic support resulting from the survey campaign of the company APR Rilievi, which we would like to thank for its cooperation.

From the wall structures still visible in the elevation of the San Pietro in Castello site, it is possible to develop some hypotheses about the castle which gives the name to the group of architectural techniques.

According to documentary evidence, the so-called castrum de Isola was already existing in the middle of the 11th century (PHASE 0). In the south front (façade) it is possible to see a limited portion of pre-existing brickwork (USM 208). The construction of the Church of San Pietro, or at least of its façade, was made in order to sustain a structure already present in situ, and it is difficult (in the absence of archaeological excavations) to determine its intended use (fig. 13).

It could be one of the towers that were part of the walls of the medieval castle, later replaced by the late Romanesque building. This building is not present in Ferretti's 1646 view; therefore, it might be supposed it was already quite defunctionalised in the middle of the 17 th century.

Other fragments of this pre-existence are visible in the walls surrounding and sustaining the east bastion of the building of San Pietro in Castello (USM 213), where there is a postern previously mentioned in the aforesaid view by Ferretti. 


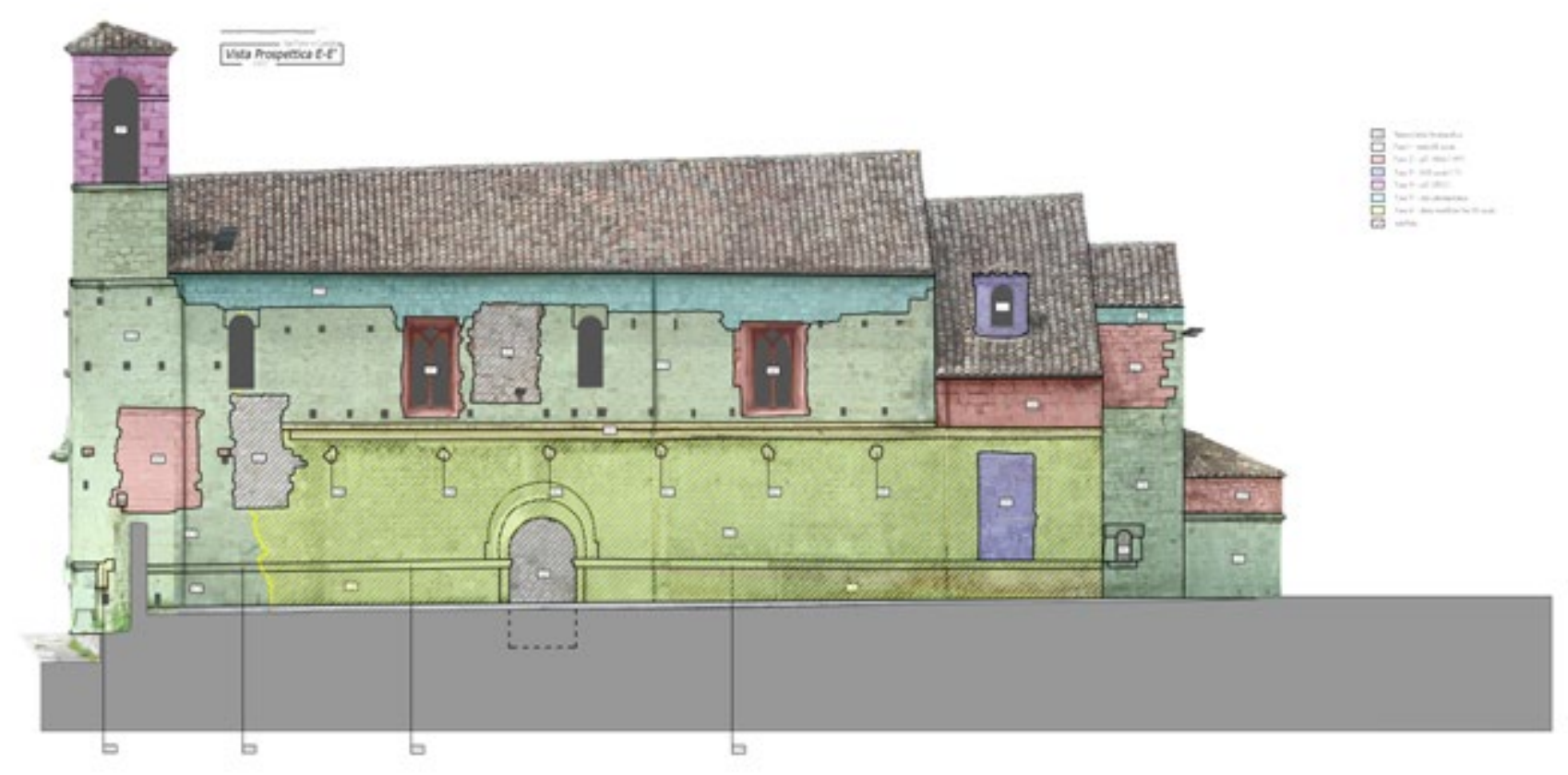

This section of the masonry was largely rebuilt in contemporary age (USM 214, 215 and 216). In fact, we can see parts reconstructed, most probably using the same building material as the medieval structure, with the insertion of fire openings, presumably fusiliers related to the conversion of the area to a military outpost. This construction site, which seriously damaged the structure of the medieval district, has probably altered in an inevitable way the archaeological sediment with the construction of underground spaces that follow the perimeter of the top hillock.

Compared to the construction and architectural techniques of San Pietro's Church, the oldest portions of the walls are characterized by the use of small and medium size lithic models, laid on horizontal and parallel rows, which are characterized by their size and by the processing of the elements, only blunted and polished with direct percussion tools.

The general plan of the present Church of San Pietro belongs to a large construction site in the area, with rebuilding of the religious structure, which probably took place in the middle of the 13th century (PHASE 1).

The façade, the apsidal basin and at least the basal part of the east elevation remain substantially the most ancient structure. Both in the façade and in the eastern perimeter there are two portals of similar type, characterized by a slightly lunar arch in the extrados. The walls are quite different between the façade, built in large, perfectly squared blocks of travertine and distributed in regular, perfectly horizontal rows, and the side walls, for which reduced-sized models of the same lithotype are used, which are installed following the same procedures as the façade, although with less attention. 


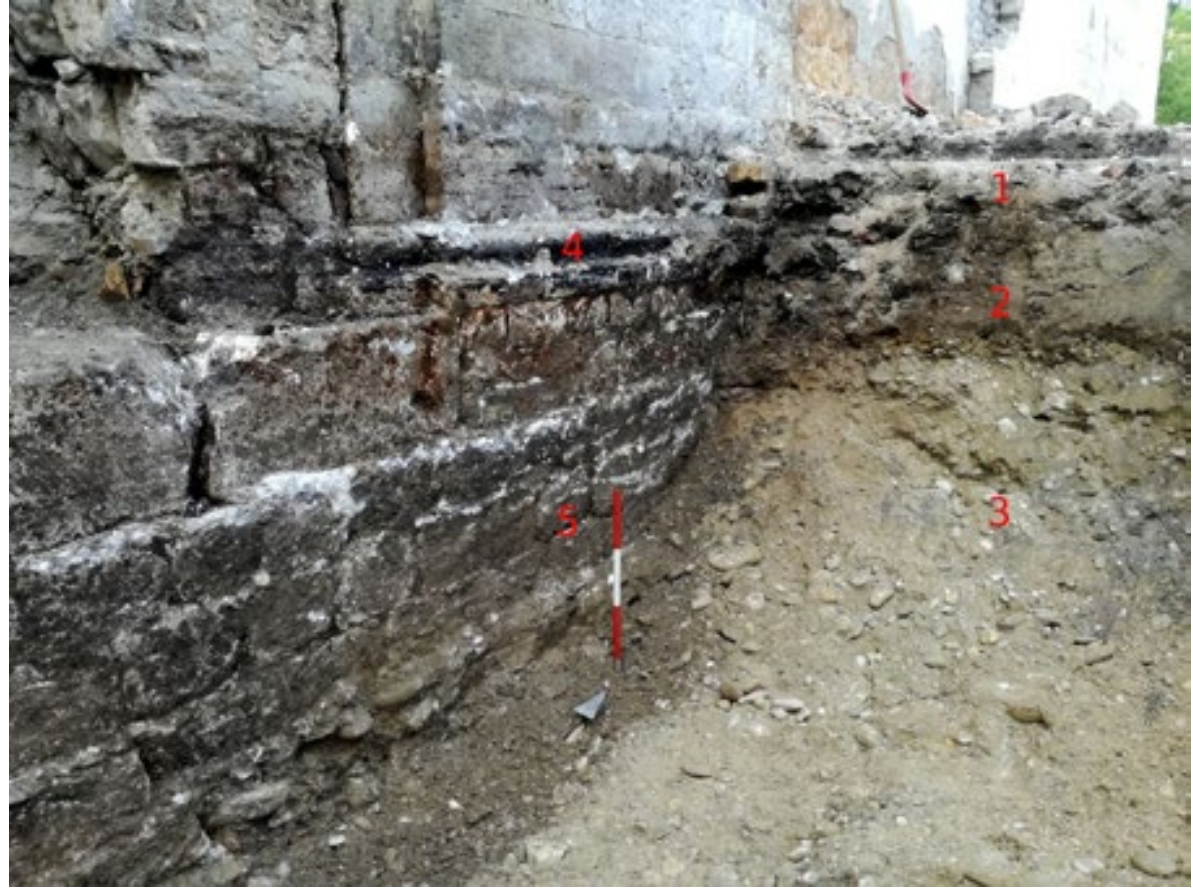

Fig. 15. A detail of the stratigraphy.

The east wall and the façade are connected by a shaped frame that breaks the masonry. This can be used as a chronological comparison with the present Church of Sant'Angelo Magno, which is also attributed to the middle of the 13th century ${ }^{20}$. Finally, also the large ogival arches that, internally, divide the nave from the presbytery, the single lancet windows of the side walls and the rose window of the façade belong to this first phase (fig. 14).

Later (PHASE 2) the church was stylistically updated to the canons of the period. This happened in the second half of the 15th century. The main evidence of these renovations are the polylobate mullioned windows that still open on the side walls today, as well as the rebuilding of the vaults in the presbytery area and the elevation of the apse basin. The archival sources describing the reconstruction works carried out in the period between 1466 and 1471 reached us in an exceptional way. Thus we know that four magistrates of Como were appointed to rebuild the building, and they were asked to portas et fenestras ponere et facere. Probably these are the same polylobate windows which illuminate the building, two for each long side, which are typologically ascribed to this period.

In the modern age (PHASE 3) several adjustments were necessary. The most obvious of these was the elevation and the construction of a dome with a central skylight in the eastern area of the presbytery enclosure, together with a niche in the thickness of the wall.

Between modern and contemporary ages, more precisely in 1850 (PHASE 4), a sail-shaped bell tower was built in the south-east corner of the church, i.e. in the right corner of the façade. The period of the construction is attested by the presence of an epigraphic date in key to the arch of the bell tower.

20 For Sant'Angelo Magno Church, please see Cappelli 2002. 
Subsequently, even if it was not at the same time (PHASE 5), the roof of the church was rebuilt, and the ridges of the west and east perimetrical ridges were partially smoothed.

Finally, there are still evident traces of the last building leaning against the church of the second half of the twentieth century (PHASE 6). At this point, a complex of buildings designed for offices and utility areas was built next to the medieval building, first as a

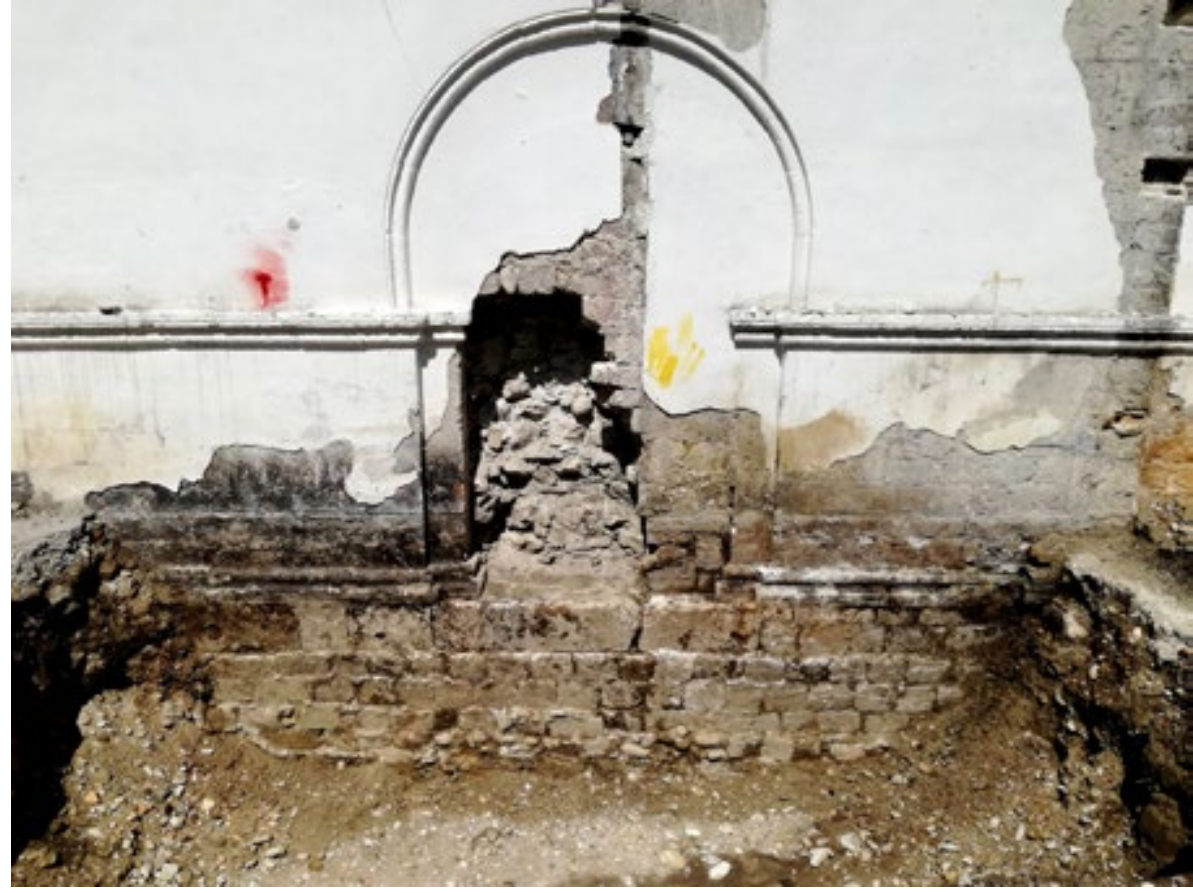

Fig. 16. Side façade $E$ of the church.

(probably during the years of World War II), and only later assigned to the $\mathrm{Mu}$ nicipal Police.

\section{Work in progress supervision and preventive surveys}

The supervision of the work in progress involved the monitoring of the demolition of buildings and modern superfetation and the subsequent removal of rubble. During this phase, two architectural elements in travertine (a Corinthian-style semi-column and an ovular decoration) were discovered and two hypogeal areas were identified: for safety reasons, these were not fully investigated and measured.

In addition, an archaeological survey has been carried out along the eastern elevation of the Church of San Pietro in Castello, in correspondence with the side walled portal that emerged after the demolition of the modern building leaning against the church.

The archaeological excavation measures $6.00 \mathrm{~m}$ in a north-south direction, $4.00 \mathrm{~m}$ in an east-west direction for a depth of about $1.80 \mathrm{~m}$. The stratigraphy highlighted the presence, below the modern walking surface and its preparation (US1, total thickness about $\mathrm{m}$ 0.30), of a level of anthropic soil (US2), thickness $\mathrm{m} 0.40$, which cannot be dated because no diagnostic materials have been found and the layer is strongly affected due to recent interventions. A high level of gravel and river deposition pebbles (US3) detected underneath the layer and investigated for more than a meter of depth (fig. 15). The side façade of the church (USM4) has been 
covered by modern surface layers and appears to be in phase with US2. The building's foundation (USM5) is set directly on the river gravel (US3) (fig. 16).

\section{Conclusions}

The surveys carried out of San Pietro in Castello highlighted important information which improves our knowledge of the site. The analysis of the elevations underlined the presence of pre-existing structures in the façade of the church and in the aforementioned postern that seem to be part of the ancient castrum, a structure certainly existing in the 11th century.

Furthermore, the geophysical non-invasive survey returned particularly useful data from within the church, providing evidence of construction phases which are likely to be earlier than the present building's 13th century design. The results of the architectural analysis and the geophysical investigation seem to agree with the historical sources, which mention the first foundation of the church at the behest of Bishop Auclere in the Longobard period, as well as several structural modifications over time.

However, in order to ascertain the geophysical data, i.e. to understand the function and chronology of these structures and their relationship with a more ancient cultic building and/or their relationship with the castrum, it would be necessary to carry out an archaeological excavation in correspondence with the anomalies found, especially inside of the church, a survey that would make the archaeological repository understandable and connect all the collected information. 


\section{Bibliography}

Andreantonelli, Sebastiano. 1673. Historiae Asculanae, Padova: Typis Matthaei de Cadorinis.

Andreantonelli, Sebastiano. 1968. Historiae Asculanae. Historiae Urbium et Regionum Rariores LXIV, Ristampa fotomeccanica, Bologna: Forni Editore.

Boschi, Federica, ed. 2016. Looking to the Future, Caring for the Past. Preventive Archaeology in Theory and Practice, Bologna: Ante Quem.

Boschi, Federica, Enrico Giorgi and Michele Silani. 2017. 'Recontructing the ancient urban landscape in a longlived city: the project Asculum between research, territorial planning and preventative archaeology'. Archeologia e Calcolatori. 28.2, 301-309.

Brogiolo, Gian Pietro, Cagnana, Aurora. 2002. Archeologia dell'Architettura. Metodi e interpretazioni. Firenze: All'Insegna del Giglio.

Calzini, Egidio, 1905. 'L'arte marchigiana'. In Rassegna bibliografica dell'arte italiana, s. VIII, 11-12, 177-180.

Cappelli, Furio. 2002. 'Gli affreschi del sottotetto della chiesa di S. Angelo Magno di Ascoli Piceno: analisi, ambientazione e inquadramento storico-culturale', in Guardate con i vostri occhi ... : saggi di storia dell'arte nelle Marche edited by Angela Montironi. Ascoli Piceno: Lamusa, 13-48.

Cappelli, Furio. 2007. Guida alle chiese romaniche di Ascoli Piceno, città di travertino. Ascoli Piceno: D’Auria Industrie Grafiche S.p.A.

Carducci, Giambattista. 1853. Su le memorie e i monumenti di Ascoli nel Piceno. Fermo: Del Monte.

Conta, Gioia. 1982. 'Il territorio di Asculum in età romana'. In: Asculum II, edited by Gioia Conta and Umberto Laffi. Pisa: Giardini, 337-451.

Conyers L.B, Goodman D. 1997. Ground Penetrating Radar: An introduction for Archaeologist Oxford: Altamira Press.

De Maria, Sandro and Enrico Giorgi. 2014. 'Asculum: cultura architettonica e figurativa di età romana'. In Storia di Ascoli dai Piceni all'epoca romana edited by Gianfranco Paci. Ascoli Piceno: Edizioni Librati, 173-222.

Fabiani, Giuseppe. 1951. Ascoli nel Quattrocento. voll. II, Vol. II. Ascoli Piceno: Società tipolitografica editrice.

Giorgi, Enrico. 2000. 'La via consolare Salaria e le sue diramazioni nel territorio'. In Atlante dei beni culturali dei territori di Ascoli Piceno e di Fermo. Beni Archeologici. Milano: Silvana, 145-53.

. 2014. 'Il territorio della colonia: viabilità e centuriazione'. In Storia di Ascoli, dai Piceni all'epoca romana I, edited by G. Paci. Ascoli Piceno: Edizioni Librati, 225-292.

Marcucci, Francesco Antonio. 1766. Saggio delle cose ascolane e de'vescovi di Ascoli nel Piceno dalla fondazione della città sino al corrente secolo decimottavo, e precisamente all'anno 1766 dell'era volgare publicato da un abate ascolano. Teramo. 
Mariotti, Cesare. 1925. Guida di Ascoli Piceno. Ascoli Piceno.

Paci, Gianfranco. 2014. Storia di Ascoli, dai Piceni all'epoca romana I. Ascoli Piceno: Edizioni Librati.

Pasquinucci, Marinella, and Umberto Laffi. 1975. Asculum. I. Storia di Ascoli Piceno nell'età antica di Umberto Laffi - Studio sull'urbanistica di Ascoli Piceno romana di Marinella Pasquinucci. Pisa: Giardini.

Profumo, Maria Cecilia. 2005. 'Schede di archeologia altomedievale in Italia: Marche'. Studi Medievali, 3, XLVI (II): 843-914.

Quilici, Lorenzo. 2007. 'La via Salaria: una grande strada di comunicazione dall'uno all'altro mare', in Studi Maceratesi 14, 65-91.

Rodilossi, Antonio. 1938. Ascoli Piceno città d'arte. Modena.

Staffa, Andrea Rosario. 2000. 'La via Salaria nella bassa valle del Tronto', in La Salaria in età antica : atti del convegno di studi, Ascoli Piceno, Offida, Rieti, 2-4 ottobre 1997 edited by Enzo Catani and Gianfranco Paci. Roma: L'Erma di Bretschneider, 417-436.

Serra, Luigi. 1936. L'arte nelle Marche, 2 vol., Pesaro-Roma.

Varese, Prospero, Angelini Rota, Giuseppe. 1942. 'Il catasto ascolano del 1381', in Atti e Memorie della Deputazione di Storia Patria per le Marche, s. VI, XXI, 43-147. 